\title{
Zn Ions Change Binding Mode of TOEPyP4 with DNA and Cause DNA Transition from $B$ to $C$ and Zn-Like Conformations
}

\author{
Jamlet Monaselidze $^{1 *}$, Maya Gorgoshidze ${ }^{1}$, David Khachidze ${ }^{1}$, Maya Kiladze ${ }^{1}$, Vasil Bregadze ${ }^{1}$, \\ Eugene Kiziria ${ }^{1}$, Hakob Margaryan ${ }^{2}$, Nune Hakobyan ${ }^{2}$ \\ ${ }^{1}$ Department of Physics of Biological Systems, Andronikashvili Institute of Physics, Tbilisi State University, Tbilisi, Georgia \\ ${ }^{2}$ Department of Radiophysics, Erevan State University, Erevan, Armenia \\ Email: ${ }^{*}$ j.monaselidze@aiphysics.ge
}

Received November 14, 2013; revised December 5, 2013; accepted December 10, 2013

Copyright (C) 2013 Jamlet Monaselidze et al. This is an open access article distributed under the Creative Commons Attribution License, which permits unrestricted use, distribution, and reproduction in any medium, provided the original work is properly cited.

\begin{abstract}
It is known that at low concentrations of TMPyP4, this porphyrin predominantly intercalates between GC pairs at GC-rich sites of duplex DNA and G-quadruplexes of various constructions, and stabilizes these structures. However, there are still some arguable suggestions about the exact binding sites and modes of TMPyP4 to GC-rich regions of DNA in case of helation of divalent ions with help of the porphrin, which makes porphyrin structure asymmetric. We examined TOEPyP4 - analogue of TMPyP4 — and studied interaction of TOEPyP4 into the calf thymus DNA at presence of nanomole concentrations of one of the most important microelements in cell vital function- $\mathrm{Zn}$ ion. On the basis of CD and absorption spectra of the DNA-TOEPyP4 mixture, it was determined that nanomole concentrations of $\mathrm{Zn}$ ions changed porphyrin intercalative binding mode to some external binding modes, which initiated transition of the canonic B conformation of DNA into C-like conformation, and incubation of the (DNA-TOEP4) $+\mathrm{Zn}$ mixture at $37^{\circ} \mathrm{C}$ caused B-Z-like transition, but no transition was observed for the DNA-TOEPyP4 mixture. In particular, at 10 $\mathrm{mM} \cdot \mathrm{NaCl}$, TOEPyP4/DNA $=0.02$, the binding mode change was observed in the concentration range from 150 to 300 $\mathrm{nM} \cdot \mathrm{Zn}$, and the B-C-like transition occurred from 150 to $600 \mathrm{nM} \cdot \mathrm{Zn}$. The B-Z transition at TOEPyP4/DNA $=0.015$, $\mathrm{Zn} / \mathrm{DNA}=0.015, \mathrm{NaCI} 10 \mathrm{mM}, \mathrm{T}=37^{\circ} \mathrm{C}$ was observed within incubation time interval from 0.3 to 20 hours, and maximal percents of Z-like form was seen when incubation time interval was from 5 to 6 hours.
\end{abstract}

Keywords: CD; Porphyrin; TOEPyP4; TMPyP4; B-C Transition; B-Z Transition

\section{Introduction}

Exclusive binding of flat TMPyP4 cation (meso-5,10,15, 20-Tetrakis-(N-methyl-4-pyridyl)) porphine porphyrin to DNA is a subject of interest in a number of fields, including molecular biology, genomics and pharmaceutical science [1-3].

It was demonstrated that TMPyP4 porphyrin that is characterized with low toxicity caries out several binding modes with DNA by intercalation between GC pairs and external groove binding. It also intercalates between stacked G-tetrads with high affinity and stabilizes the quadruplex complex, inhibits telomerase and detains growth of transformed cells in many human tumors [4,5]. This unique properties of TMPyP4 to selectively bind to

${ }^{*}$ Corresponding author.
GC-rich DNA sites capable to form G-quadruplexes may be lost if TMPyP4 binds to divalent ions, due to which porphyrin structure becomes asymmetric. It was also shown that the axial ligand ZnTOEPyP4 (meso-tetra(4N-oxyethylpyridil)) performed an external binding mode and initiated a strong increase of DNA thermopstability [6], as well as transition from B to Z-like conformation [7]. It was also shown that high concentrations of TOEPyP4 initiated transformation of poly[d(A-T)d(A-T)] but not ply $(\mathrm{G}-\mathrm{C})$ into Z-like conformation, when TOEPyP4/ $\mathrm{DNA}=0.23[8,9]$. It should be noted that presence of physiological concentrations of alkaline-earth metal ions initiate formation of G-quadruplex in GC-rich sites of DNA, and extremely high concentrations of the same ions cause $\mathrm{B} \rightarrow \mathrm{C}$ and $\mathrm{B} \rightarrow \mathrm{Z}$-like transitions [10,11].

In this work, we demonstrate that the $\mathrm{B} \rightarrow \mathrm{C}$ and $\mathrm{B} \rightarrow$ 
Z-like transitions are initiated by the change of intercalation to external binding mode in case of combined influence of nanogram concentrations of TOEPyP and $\mathrm{Zn}$ ions.

\section{Experiments and Methods}

CD (Circular Dichroism) spectra were recorded on spectropolarimeter JASCO $500 \mathrm{~A}$ at $20^{\circ} \mathrm{C}$. Absorption spectra were recorded on spectrophotometer UNICAM SP 1800 (UK). For both CS and absorption spectra we used $1.0 \mathrm{~cm}$ quartz cells. CD is shown in millidegree of ellipticity. The water-soluble meso-tetra(4-N-oxyethylpyridil) porpyrin (TOEPyP4) was synthesized in ESU according to the method described in work [18]. Calf thymus DNA was purchased from Sigma. Please see [12] for more detailed information.

\section{Experimental Data}

\subsection{Absorption Spectra}

The absorption spectra of TOEPyP4 and $\mathrm{Zn}$ ions mixture incubated during various times at $37^{\circ} \mathrm{C}$ were recorded. It was demonstrated that a complex was formed in the mixture after 45 min incubation, the spectrum of which was similar to spectrum of Zn-TOEPyP4 complex at $\lambda=$ $440 \mathrm{~nm}$.

The absorption spectra were recorded for TOEPyP4, native DNA-TOEPyP4, denaturated DNA-TOEPyP4, as well as (DNA-TOEPyP4) $+\mathrm{Zn}$ complexes incubated at $37^{\circ} \mathrm{C}$ during 2,8 , and 24 hours at $10 \mathrm{mM} \cdot \mathrm{NaCI}$ (see Figure 1). It was clearly shown that incubation of triplex complrx from 0 to 24 hours did not cause any spectrum changes at $260 \mathrm{~nm}$, but caused a shift of the absorption maxima of the complex to the higher wavelength area by $18 \mathrm{~nm}$, i.e. a Zn-TOEPyP4 complex formation took place. Denaturation of the (DNA-TOEPyP4) + Zn complex by incubation for $24 \mathrm{~h}$ caused an $38 \%$ increase of the absorption peak intensity at $260 \mathrm{~nm}$, but it did not change intensity and wavelength of the peak initiated by porphyrin in the Soret region $(440 \mathrm{~nm})$.

\subsection{Studies}

Figure 2 shows visual and UV CD spectra of (DNATOEPyP4) $+\mathrm{Zn}$ triple complex at presence of low concentrations of added $\mathrm{Zn}$ ions at $10 \mathrm{mM} \cdot \mathrm{NaCl}$. As it is seen from Figure 2, increase of $\mathrm{Zn}$ ion concentration in a narrow concentration region from $150 \mathrm{nM}$ to $300 \mathrm{nM}$ that corresponds to mixing molar ratio $\mathrm{Zn} / \mathrm{DNA}=\mathrm{r}$ from 0.005 to 0.01 causes disappearance of the negative CD band at about $440 \mathrm{~nm}$, which reflects intercalation binding mode, and a 30\%-increase of $\mathrm{CD}$ band maximum intensity around $420 \mathrm{~nm}$, which corresponds to a groove binding mode of porphyrin [13], and a shift of the peak



Figure 1. Absorption spectra of TOEPyP4 (1), DNA (2), DNA-TOEPyP4 (3), and (DNA-TOEPyP4) + Zn complex incubated at $37^{\circ} \mathrm{C}$ for different times: $2 \mathrm{~h} \mathrm{(4),8} \mathrm{h} \mathrm{(5),} 24 \mathrm{~h}$ (6), preliminarily denaturated sample (6) at $100^{\circ} \mathrm{C}$ during 15 minutes, and then cooled to $70^{\circ} \mathrm{C}$ and measured at $75^{\circ} \mathrm{C}$ (7). Molar ratios TOEPyP4/DNA $\mathrm{App}=0.02, \mathrm{Zn} / \mathrm{DNA} A_{\mathrm{bp}}$ $=0.015$; and DNA $=30 \mu \mathrm{M}$ in $10 \mathrm{mM} \cdot \mathrm{NaCI}$.

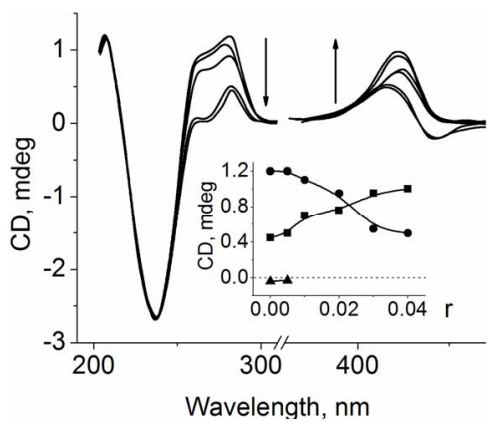

Figure 2. CD visual and UV spectra of DNA-TOEPyP4 complex plus $\mathrm{Zn}$ ions at molar mixture ratio TOEP4/DNA $=0.02,10 \mathrm{mM} \cdot \mathrm{NaCI}$. DNA $=30 \mu \mathrm{M}$. Zn/DNA = r:0; 0.005; $0.01 ; 0.02,0.027 ; 0,035$. Insertion: Dependences of $C D$ spectra intensity on $r$ at $285 \mathrm{~nm}(\bullet), 420 \mathrm{~nm}(\bullet)$, and 440 $\mathrm{nm}(\Delta)$, the arrows show increase of $\mathrm{Zn}$ ions concentration.

to the longer wavelength region by $3-4 \mathrm{~nm}$ at increase of $r$. Dependence of intensities of these bands on $r$ is presented in Figure 2. Figure 2 shows that the increase of $\mathrm{Zn}$ ions concentration causes a decrease of the positive DNA band intensity around $280 \mathrm{~nm}$ and splitting of this band. Dependence of band maxima at $285 \mathrm{~nm}$ on $\mathrm{Zn}$ ion concentration has S-like curve form that indicates at a cooperative change of DNA conformation.

At high concentration of $\mathrm{Na}$ ions $(100 \mathrm{mM} \cdot \mathrm{NaCl})$ and mixing ratio TOEPyP4/DNA $=0.02$, when the negative charge of phosphate groups were partially screened by $\mathrm{Na}$ ions, the impact of $\mathrm{Zn}$ ions in intercalative binding mode and DNA conformation was weakened. This type of binding disappears at $\mathrm{r}=0.025$, i.e. at $\mathrm{Zn}$ ions concentration that is 5 times more than at $10 \mathrm{mM} \cdot \mathrm{NaCl}$. Beside this, the dependence of the changes of both positive bands on $\mathrm{r}$ at $285 \mathrm{~nm}$ and $420 \mathrm{~nm}$ has an exponential character and occure simultaneously (see Figure 3).

The influence of $\mathrm{Zn}$ ions on binding mode of TOEPyP4 with DNA became also weaker when $\mathrm{NaCl}$ molar con- 


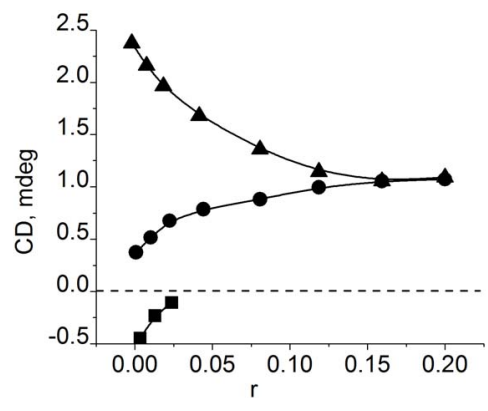

Figure 3. Dependences of CD spectra intensity on $r$ at 285 $\mathrm{nm}(\Delta), 420 \mathrm{~nm}(\bullet)$, and $440 \mathrm{~nm}(\bullet)$, at $100 \mathrm{mM} \cdot \mathrm{NaCl}$, TOEPyP4/DNA

centration remained constant $(10$ and $100 \mathrm{mM})$ and porphyrin concentration increased. For example, when TOEPyP4/DNA $=0.05$ at $10 \mathrm{mM} \cdot \mathrm{NaCl}$, at presence of $\mathrm{Zn}$ ions, the intercalation binding mode disappeared at $\mathrm{r}$ $=0.1$ (the data are not presented).

The decrease of intensity at $285 \mathrm{~nm}$ as a result of splitting of the DNA positive band around $280 \mathrm{~nm}$, and invariability of the negative band around $245 \mathrm{~nm}$ at addition of $\mathrm{Zn}$ ions, point at transition of the canonic B DNA form into C-like conformation, according to the published data [10].

Different incubation times of the triple complex (DNATOEPyP4) + Zn gave us some new additional information about structures and stability of this complex. Figures 4(a)-(e) present $C D$ spectra and dependences of band intensities of DNA-TPEPyP4 and (DNA-TPEPyP4) $+\mathrm{Zn}$ complexes on incubation times at $37^{\circ} \mathrm{C}$ and 10 $\mathrm{mM} \cdot \mathrm{NaCl}$. The presented data show that incubation of the complexes without metals for 6 hours at $37^{\circ} \mathrm{C}$ leads to some weak changes in $\mathrm{CD}$ spectra in visible and UV regions. Further increase of the incubation time (from 6 to 20 hours) leads to disepearence of the negative band at $440 \mathrm{~nm}$ and the decrease the positive band at $420 \mathrm{~nm}$, as well as smoothed profile and increased intensity of the positive band around $280 \mathrm{~nm}$ (Figures 4(b)-(e)). The 40 $\mathrm{h}$ and $72 \mathrm{~h}$ incubations cause a good recovery of the UV CD spectra of DNA-TOEPyP4 complex, and practically full disappearance of absorption bands in the Soret region. Figure 4(d) shows only the DNA-TOEPyP4 complex UV CD spectrum.

The other picture was observed in case of triple complex incubation at $37^{\circ} \mathrm{C}$. In this case, some significant changes in CD spectrum were observed in both UV and Soret regions during the first six hours. In this time interval, intensity of the negative band at $440 \mathrm{~nm}$ changed from negative sign to positive one, the positive bands of these complexes at $420 \mathrm{~nm}$ decreased, but splitting of the positive band of DNA at $280 \mathrm{~nm}$ by TOEPyP4 and metal ions at $260 \mathrm{~nm}$ and $285 \mathrm{~nm}$ was changed. In particular, the band intensity at $285 \mathrm{~nm}$ dropped to null, the band intensity at $260 \mathrm{~nm}$ weakly changed, the intensity of the
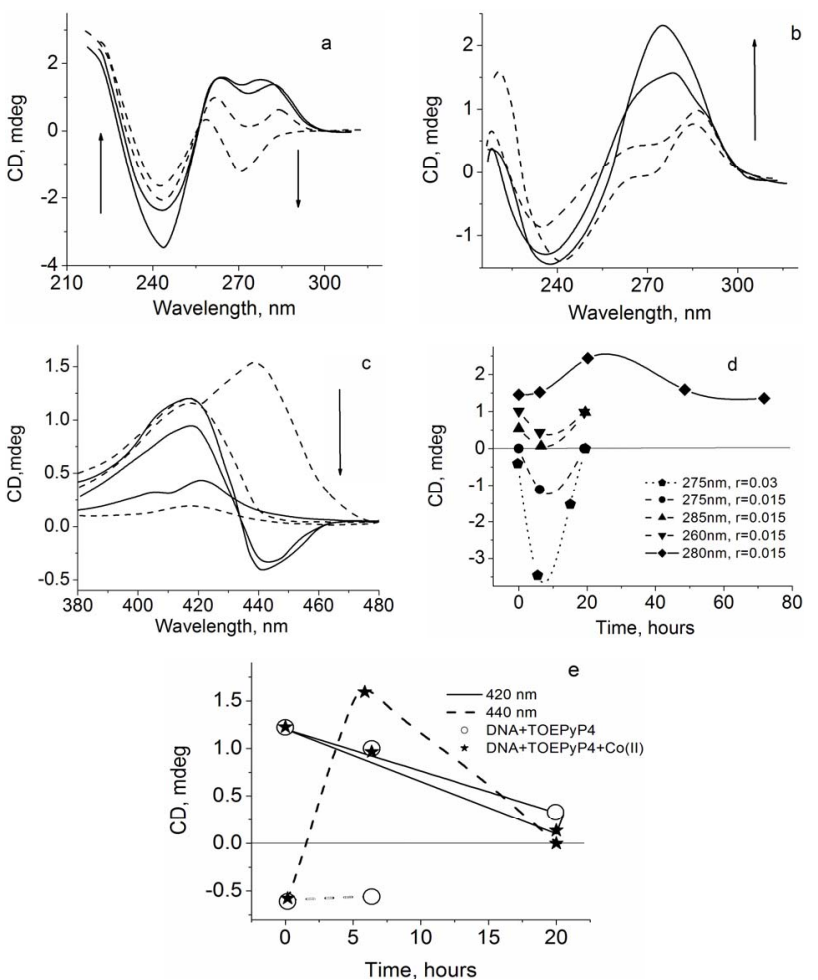

Figure 4. (a)-(c) Visual and UV CD spectra of DNA-TOEPyP4 complex (solid line) and DNA-TOEPyP4 $+\mathrm{Zn}$ complex (dashed line), TOEPyP4/DNA $A_{\text {b.p }}=0.015, \mathrm{Zn} / \mathrm{DNA}_{\text {b.p }}=0.015$, pH 7.02, $10 \mathrm{mM} \cdot \mathrm{NaCl}$; (d), (e) Dependence of the bands intensity of DNA-TOEPyP4 and DNA-TOEPyP4 + Zn complexes on time. DNA $=34 \mu \mathrm{M}$, arrows show increase of $\mathrm{Zn}$ ions concentration.

basic negative band at $245 \mathrm{~nm}$ decreased, and an individual new negative band at $275 \mathrm{~nm}$ appeared and its intensity reached maximum on the sixth hour of incubation. Intensity of the negative band at $275 \mathrm{~nm}$ and the positive band at $260 \mathrm{~nm}$ were comparable (Figures 4(a) and (d)). This, the CD spectra of these complexes in UV region become like to spectra of $Z$ form polynucleotide poly[d(A-T)d(A-T)] in presence of high TOEPyP4/DNA $\geq 0.23[8,9]$.

\section{Discussion}

According to data [6-14], the cation porphyrins TOEPyP4, Me-TOEPyP4, and TMPyP4 are strong stabilizing agents of DNA, its synthetic analogues and G-quadruplexes [15]. These porphyrins bind to DNA and polynucleotides, and form two main binding modes-intercalation into GCrich regions and external groove binding in AT-rich regions $[8,13,16]$. Both binding modes are able to transfer DNA and polynucleotides from B to Z-like conformation $[8,9]$. In the work [10], it was shown that transition metal ions, including $\mathrm{Mg}$ and $\mathrm{Zn}$ ions, make octahedral complexes $\mathrm{Me}\left[\left(\mathrm{H}_{2} \mathrm{O}\right)_{6}\right]^{+2}$ that can be high effectively absorbed into the minor groove of C-like DNA sites, they are ca- 
pable to wind the double helix and cause narrowing of minor groove of the duplex, and this narrowing leads to transition of DNA from $\mathrm{B}$ form to $\mathrm{C}$-like and T-like conformations [10].

We suggest that the observed B-C-like transition in case of the triple complex occurs due to the joint influence of porphyrin and a metal ion on DNA in which TOEPyP4 is an initiator of this transition. In particular, the surface near groove and groove bindings at AT-rich sites [13] initiate formation of a C-like conformation in those local regions. Addition of nanomole concentrations of $\mathrm{Zn}$ ions that effectively bind to these regions due to a steric compliances of a hydrated ion with size of minor groove of the C-like DNA causes further effective winding of $\mathrm{C}$-like conformation helix that leads to narrowing a minor groove and decrease of the distance between flats of DNA base pairs [17]. As a result, due to the steric conditions of TOEPyP4, it cannot stay intercalated and moves into the solution, it does not bind to $\mathrm{Zn}$ ions for a short period of time (see above and also Figure 1) and forms a surface groove binding that causes some changes to CD spectra, namely, disappearance of the negative band at about $440 \mathrm{~nm}$, increase of the positive band at $420 \mathrm{~nm}$ by $30 \%$ in Soret region, decrease of the positive band at $285 \mathrm{~nm}$, and invariability of the negative band at $245 \mathrm{~nm}$. All of these demonstrate the $\mathrm{B} \rightarrow \mathrm{C}$ transition of DNA (see Figure 2).

A different picture was observed when incubation of DNA-TOEP4 complex at presence of $\mathrm{Zn}$ ions. In this case, because of the fact that the binding constant of TOEPyP4-DNA is by two orders of magnitude than the binding constant of Me-DNA [18,19], after some minutes at $37^{\circ} \mathrm{C}$, TOEPyP4 occupies the same sites that have been occupied by the metal ions, and then this porphyrin binds to those metals forming Zn-TOEPyP4 complex form two modes of binding. These binding modes are reflected on CD spectra as two positive bands with maxima at about $420 \mathrm{~nm}$ and $440 \mathrm{~nm}$ (Figure 4(c)). The intensities of these bands are significantly higher in comparison with the some bands at $20^{\circ} \mathrm{C}$ at identical TOEPyP4/DNA ratios [12]. Consequently, the influence of $\mathrm{Zn}$-TOEPyP4 complex on DNA at $37^{\circ} \mathrm{C}$ is more effective than at $20^{\circ} \mathrm{C}$. We suppose that this is the main factor that provokes DNA transition from B to Z-like conformation, which happens slowly_-within 6 hours of incubation.

\section{Summery}

Analysis of the obtained CD and spectrophotometer results revealed the following: 1) combined influence of nanomole concentrations of $\mathrm{Zn}$ ions and cation TOEPyP4 porphyrin initiates a DNA transition from its canonic B form to C-like conformation; and 2) $\mathrm{B} \rightarrow \mathrm{Z}$ transition of DNA in (DNA-TOEPyP4) $+\mathrm{Zn}$ mixture appears due to an external binding of ZnTOEPyP4 to DNA, at $37^{\circ} \mathrm{C}$.
We think that these data will be interesting for pharmacologists and medical specialists who use the above mentioned porphyrins in cancer chemotherapy, because divalent ion concentration is increased in many human cancers compared to the norm.

\section{Acknowledgements}

This work is supported by the IPP/ISTC A-1951 Project.

\section{REFERENCES}

[1] C. L. Grand, H. Han, R. M. Munoz, S. Weitman, D. D. Von Hoff, L. H. Hurley and D. J. Bearss, "The Cationic Porphyrin TMPyP4 Down-Regulates c-MYC and Human Telomerase Reverse Ttranscriptase Expression and Inhibits Tumor Growth in Vivo," Molecular Cancer Therapeutics, Vol. 1, No. 8, 2002, pp. 565-573.

[2] N. Nagesh and A. Ganesh Kumar, "Interaction of TMPyP4, TMPyP3, and TMPyP2 with Intramolecular G-Quadruplex Formed by Promoter Region of $\mathrm{Bcl} 2$ and KRAS NHPPE," ISRN Biophysics, Vol. 2012, 2012, Article ID: 786596.

[3] D. J. Cashman, R. Buscaglia, M. W Freyer, J. Dettler, L. H. Hurley and E. A. Lewis, "Molecular Modeling and Biophysical Analysis of the c-MYC NHE-III1 Silencer Element," Journal of Molecular Modeling, Vol. 14, No. 2, 2008, pp. 93-101.

http://dx.doi.org/10.1007/s00894-007-0254-Z

[4] E. Izbicka, R. T. Wheelhouse, E. Raymond, K. K. Davison, R. A. Lawrence, D. Sun, B. E. Windle, L. H. Hurley and D. D. Von Hoff, "Effects of Cationic Porphyrins as G-Quadruplex Interactive Agents in Human Tumor Cells," Cancer Research, Vol. 59, No. 3, 1999, pp. 639-644.

[5] Z. Zhang, J. Dai, E. Veliath, R. A. Jones and D. Yang, "Structure of a Two-G-Tetrad Intramolecular G-Quadruplex Formed by a Variant Human Telomeric Sequence in $\mathrm{K}^{+}$Solution: Insights into the Interconversion of Human Telomeric G-Quadruplex Structures," Nucleic Acids Research, Vol. 38, No. 3, 2008, pp. 1009-1021. http://dx.doi.org/10.1093/nar/gkp1029

[6] J. Monaselidze, G. Majagaladze, Sh. Barbakadze, D. Khachidze, M. Gorgoshidze, Y. Kalandadze, S. Haroutiunian, Y. Dalyan and V. Vardanyan, "Microcalorimetric Investigation of DNA, Poly(Da)Poly(Dt) and Poly[D(AC)]Poly[D(G-T)] Melting in the Presence of Water Soluble (Meso Tetra (4 N Oxyethylpyridyl) Porphyrin) and Its Zn Complex," Journal of Biomolecular Structure and Dynamics, Vol. 25, No. 4, 2008, pp. 419-424. http://dx.doi.org/10.1080/07391102.2008.10507190

[7] Y. Dalyan, S. Haroutiunian, G. Ananyan, V. Vardanyan, V. Madakyan, R. Kazaryan, L. Saakyan, L. Messory, P. Orioli and A. Benight, "Interaction of Meso-Tetra-(4-Noxyethylpyridyl) Porphyrin, Its 3-N Analog and Their Metallo-Complexes with Duplex DNA," Journal of Biomolecular Structure and Dynamics, Vol. 18, No. 5, 2001, pp. 677-687.

http://dx.doi.org/10.1080/07391102.2001.10506698

[8] M. J. Carlin, E. Mark and R. Fiel, "Intercalative and Non- 
intercalative Binding of Large Cationic Porphyrin Ligand to Polynucleorides," Nucleic Acids Research, Vol. 11, No. 17, 1983, pp. 6141-6153. http://dx.doi.org/10.1093/nar/11.17.6141

[9] R. T. Fiel, "Porphyrin Nucleic Acid Interaction," Journal of Biomolecular Structure and Dynamics, Vol. 6, No. 6, 1989, pp. 1259-1274. http://dx.doi.org/10.1080/07391102.1989.10506549

[10] V. I. Ivanov, L. E. Minchenkova, A. K Schyolkin and A. I. Poletoyev, "Different Conformations of Double-Stranded Nucleic Acid in Solution as Revealed by Circular Dichroism," Biopolymers, Vol. 12, No. 1, 1973, pp. 89-110. http://dx.doi.org/10.1002/bip.1973.360120109

[11] K. Jaroslav, I. Kejnovská, D. Renčiuk and M. Vorlíčková, "Circular Dichroism and Conformational Polymorphism of DNA," Nucleic Acids Research, Vol. 37, No. 6, 2009, pp. 1713-1725. http://dx.doi.org/10.1093/nar/gkp026

[12] J. Monaselidze, E. Kiziria, M. Gorgoshidze, D. Khachidze, M. Kiladze, E. Lomidze, H. Margaryan and N. Hakobyan, "CD and DSC Investigation of Individual and Complex Influence of Meso-Tetra(4-Oxiethylpyridil) Porphyrin (TOEPyP4) and Its Zn-Complex on DNA," American Journal of Analytical Chemistry, Vol. 3, No. 10, 2012, pp. 698-703.

[13] S. Lee, Y. A. Lee, J. Y. Lee, D. H. Kim and S. K. Kim, "Rotation of Periphery Methylpyridine of Meso-Tetrakis(n-N-Methylpyridiniumyl)Porphyrin $(\mathrm{n}=2,3,4)$ and Its Selective Binding to Native and Synthetic DNAs," Biophysical Journal, Vol. 83, No. 1, 2002, pp. 371-381. http://dx.doi.org/10.1016/S0006-3495(02)75176-X
[14] J. Monaselidze, M. Kiladze, M. Gorgoshidze, D. Khachidze, V. Bregadze, E. Lomidze and T. Lezhava, "Microcalorimetric Study of DNA-Cu(II)TOEPyP4 Porphyrin Complex," Journal of Thermal Analysis and Calorimetry, Vol. 108, No. 1, 2012, pp. 127-131.

[15] J. M. Dettler, R. Le. Buscaglia and E. A. Lewis, "DSC Deconvolution of the Structural Complexity of c-MYC P1 Promoter G-Quadruplexes," Biophysical Journal, Vol. 100, No. 6, 2011, pp. 1517-1525. http://dx.doi.org/10.1016/j.bpj.2011.01.068

[16] M. Benett, A. Krah, F. Wien, F. Carman, R. Mekenna, M. Sanderson and S. Neidle, "A DNA-Porphyrin MinorGroove Complex at Atomic Resolution: The Structural Consequences of Porphyrin Ruffing," Proceedings of the National Academy of Sciences, Vol. 97, No. 17, 2000, pp. 9476-9481. http://dx.doi.org/10.1073/pnas.160271897

[17] W. Saenger, "Principles of Nucleic Acid Structure," Springer, New York, 1984. http://dx.doi.org/10.1007/978-1-4612-5190-3

[18] M. A. Sari, J. P. Battioni, D. Dupré, D. Mansuy and J. B. Le Pecq, "Interaction of Cationic porphyrins with DNA: Importance of the Number and Position of the Charges and Minimum Structural Requirements for Intercalation," Biochemistry, Vol. 29, No. 17, 1990, pp. 4205-4215. http://dx.doi.org/10.1021/bi00469a025

[19] T. Ohyama, H. Mita and Y. Yamamoto, "Study on the Complexation between DNA and Cationic Porphyrin Derivatives," Nucleic Acids Symposium Series, Vol. 48, No. 1, 2004, pp. 137-138.

http://dx.doi.org/10.1093/nass/48.1.137 